\title{
The Internationalization of Internal Conflicts-Threatening the State. Edited by Amy L. Freedman. London and New York: Routledge, 2014. ISBN13:978-0-415-50789-9. Notes. Sources cited. Index. 280 pages.
}

Jeffrey A. James, Ph.D.

American Military University

Follow this and additional works at: https://digitalcommons.usf.edu/jss

pp. 61-62

\section{Recommended Citation}

James, Ph.D., Jeffrey A.. "The Internationalization of Internal ConflictsThreatening the State. Edited by Amy L. Freedman. London and New York: Routledge, 2014. ISBN13:978-0-415-50789-9. Notes. Sources cited. Index. 280 pages.." Journal of Strategic Security 7, no. 2 (2014) : 61-62.

DOI: http://dx.doi.org/10.5038/1944-0472.7.2.9

Available at: https://digitalcommons.usf.edu/jss/vol7/iss2/10

This Book Review is brought to you for free and open access by the Open Access Journals at Digital Commons @ University of South Florida. It has been accepted for inclusion in Journal of Strategic Security by an authorized editor of Digital Commons @ University of South Florida. For more information, please contact digitalcommons@usf.edu. 
The Internationalization of Internal Conflicts-Threatening the State. Edited by Amy L. Freedman. London and New York: Routledge, 2014. ISBN13:978-0-415-50789-9. Notes. Sources cited. Index. 280 pages. 
James, Ph.D.: The Internationalization of Internal Conflicts

\section{The Internationalization of Internal Conflicts-Threatening the State. Edited by Amy L. Freedman. London and New York: Routledge, 2014. ISBN13:978-0-415- 50789-9. Notes. Sources cited. Index. 280 pages. $\$ 155.00$ list.}

This book is a collection of seven articles dealing with various international conflicts of note, plus three added chapters of introduction, a theoretical chapter, and a conclusion. Four of the state conflict chapters were published earlier, in 2007. The author is Professor and Chair of the Political Science/International Studies program at Long Island University, New York. She has published at least two additional books dealing with political participation of minorities, and democracy in Asia today, as well as numerous articles and journal submissions.

This subfield of international relations is too little addressed, and Freedman's collection is a useful addition, almost a reminder of the all too frequent assumption that there is a boundary between domestic conflicts and international involvement in them. Each country study examines the domestic roots of the conflict, sometimes historically derived and often ethnoreligious in nature. The country studies examine how international actors were drawn into the dispute, and how they affected the outcome.

The editor's stated purpose in this volume is to examine the conditions by which domestic conflicts become "opportunities" for involvement by regional or global actors. The word "opportunities" seems unfortunate, in that external engagement is often not positive.

The volume is attempting to make a theoretical statement as to what variables may most strongly influence the causal linkages between domestic conflicts and international relations. The point is made that these have for too long been considered separately, and that may be true, although two examples spring to mind: the role of international influences in the American War of Independence and the Civil War. This theoretical focus of the book via the country case studies does not necessitate currency, but the dated nature of the articles does cause the conclusions about their relevance to the theoretical question to be diminished. Now, in 2014, conditions on the ground in Iraq, Liberia, Sierra Leone, the Philippines, Indonesia, and Thailand have altered dramatically, diminishing the comparative strength of each country case study accordingly.

Further, the considerations do not include several highly noteworthy additional case studies that might have been used, those being the case of Darfur, and international intervention resulting in South Sudan. The Syrian civil war has been ongoing now for several years, and might have added a contemporary "feel" to the discussions, as might Colombian, Northern Ireland, SpanishBasque, or Catalonian examples.

As a result, the approach made here has a dated feel, lacking empirical rigor. The editor's position might have been hypothesized and then challenged or supported with conflict data. There is a helpful chart in the first chapter that subjectively indicates the relationships among internationalization, democratization, and peace. One might have hoped for this analytic rigor to have been extended for more powerful conclusions to be drawn.

Finally, there is scant attention paid to the "R2P" debate (cited anew by G. John Ikenberry, in Foreign Affairs, May/June, 2014, p. 80), the budding "responsibility to protect" notion that influenced Western engagement in Bosnia-Kosovo, which colors assessments of engagement in Syria currently, and perhaps Ukraine as well. It might have featured largely in the RwandanZairian (DRC) chapter, or indeed others, but does not. The United States' non-engagement in the Rwandan genocide has been called by President Clinton his biggest foreign policy mistake. 
Despite these lapses, the real tangible value of the book lies in its detailed consideration of each country's conflict. For country experts, or "area study" scholars, the intensive discussions about conflict in each country will prove invaluable. Any one chapter provides an excellent factual accounting of the development, or emergence of the crises, along with superb references and notes of value. In several cases, the complexities of conflicts in Rwanda and DRC, and Aceh, for example, are fascinatingly and expertly extricated from the abstruse ethno-geopolitical circumstances likely to bewilder non-expert readers.

To the extent that peace-building is a process derived in part from effective intelligence activities coupled with counterterrorism processes, the book is relevant and useful. But one has to reach a bit for this connection; the editor's stated conclusion is that "a combination of greater democratization internally, coupled with constructive outside mediation efforts, can produce conditions necessary to prevent conflicts from escalating or diffusing, and can facilitate peacebuilding" (i).

Ultimately, this book is worth reading by two audiences, country experts seeking a richer understanding of the domestic conflicts within the areas of their expertise, and how these were influenced by externalities; and secondly, by international relations theorists seeking the nexus between domestic conflicts and international behaviors. There does not seem to be a strong relevance to intelligence studies, although there is material helpful to the study of counterinsurgency movements. The book's price reflects contemporary academic publishing problems, as the price is near scandalous except for libraries and institutions where this volume would serve numerous users.

Jeffrey A. James, Ph.D., American Military University 